\title{
Integrating portfolios into learning strategy-based instruction for EFL college students*
}

NAE-DONG YANG

\begin{abstract}
What teachers can do to facilitate their students' learning and develop autonomy has been one of the major concerns in second language instruction. This article explores the use of portfolios as a tool to facilitate student learning and develop learner autonomy. A pilot study with a class of 42 college students in 2000-2001 and then a formal study with a class of 45 students in 2001-2002 were conducted. Portfolios were integrated into the framework and procedures - i.e., diagnosis, preparation, instruction, and evaluation - for strategy training in a freshman English course at a four-year public university in Taiwan. Students' English proficiency was tested via a pretest and a post-test. Information about students' beliefs and attitudes about using portfolios and their learning style preferences was collected by both open-ended and Likert-scaled questionnaires. The study found that portfolios raised students' awareness of learning strategies, facilitated their learning process, and enhanced their self-directed learning.
\end{abstract}

\section{Introduction}

The importance of helping students to become effective and autonomous learners has been recognized by many second language teachers and researchers in recent years. It is also the goal of language learning strategy instruction (Oxford 1990; Oxford and Leaver 1996; Wenden 1991). Williams and Burden (1997), for example, have pointed out that language teachers should go far beyond the transmission of knowledge and should empower students by assisting them in acquiring the knowledge, skills, and strategies needed to become autonomous learners who can take responsibility for their own learning.

Since little research has been done concerning the use of portfolios with college students in an English as a foreign language (EFL) environment, this study investigated the effectiveness of integrating portfolios into a learning strategy- 
based EFL course. The study also explored the effects of portfolios on helping college students to become effective, autonomous learners.

The organization of this article is as follows. Section 2 presents a review of relevant literature, followed by the significance of the study (Section 3), the research questions (Section 4), and the methodology (Section 5). Section 6 offers results and discussion, followed by caveats snd suggestions (Section 7), and conclusions (Section 8).

\section{Research review}

\subsection{Nature and use of portfolios}

As a purposeful collection of student work, portfolios show student effort, progress, achievement, and self-reflection in one or more areas (Paulson and Paulson 1991). Portfolios have been used as an assessment device in composition instruction, in other disciplines, and in a variety of educational programs. As the use of portfolios may encourage students to take more initiative and control of their learning, to become more autonomous learners, and to reflect on their learning over time, portfolios may be a useful tool for learner training.

Portfolios are collections of students' work selected by the students (with the teacher's guidance) to represent their learning experiences. Just as an artist or a designer gathers paintings and works in a portfolio to show prospective clients, portfolios usually involve students selecting and gathering samples of their second language use (such as compositions and video clips) into a folder to show peers, parents, and others. Paulson, Paulson, and Meyer (1991) described portfolios as an intersection of instruction and assessment. A portfolio should include information about the activities that produced the portfolio, the process of development (possibly including drafts and revisions), and a narrative in which the student reflectively describes the learning that took place. Materials in the portfolio can represent the whole learning content (Gottlieb 1995; Yueh 1999). Portfolios provide a type of personal assessment that is directly related to classroom activities. That is why they are deemed particularly appropriate for assessing language learning processes (Belanoff and Dickson 1991; O'Malley and Pierce 1996).

Portfolios have thus become a popular method of assessment in recent years. Interest in portfolios as assessment devices first emerged in the field of composition instruction, but it evolved almost concurrently in other disciplines in the language arts such as reading, literacy, and oral language development (e.g., Farr and Tone 1994; Hewitt 1994). Portfolio assessment was then adopted in teacher training and various educational programs at different levels (e.g., Mokhtari et al. 1996; Reed 1997; Spence and Theriot 1999). English teachers have also used portfolios to evaluate and enhance student learning (e.g., Fradd and Hudelson 1995; Murphy 1997). 
A number of differences exist between portfolios and traditional assessment, according to existing research (e.g., O'Malley and Pierce 1996; Paulson and Paulson 1991). First, portfolios can assess students' learning in a wide range of areas, while more traditional assessment can only evaluate students in limited areas. Second, students participate in the process of portfolio evaluation, while more traditional assessment is teacher-centered and usually conducted in a more mechanical way. Third, portfolios take individual differences into consideration, while more traditional assessment uses the same test for everyone. Fourth, while the teacher is the only evaluator in traditional assessment, portfolio evaluation involves everybody in the assessment process, including students, teachers, and peers. Fifth, self-evaluation is one of the learning objectives for portfolios, but not for traditional assessment. Sixth, portfolio evaluation stresses improvement, effort, and achievement, while traditional assessment only focuses on results. Finally, portfolios connect learning, assessment, and instruction whereas these three aspects are separated in traditional assessment. In brief, portfolios are considered a better tool for student learning.

The advantages of using portfolios include offering students a concrete way to value their work, reflect on their performance, enhance their learning and autonomy, alter their views of the teacher's role and their own role, encourage themselves to take responsibility for their learning, and involve themselves in the assessment process (Brown 1998; Paulson, Paulson, and Meyer 1991; Yueh 1999). Through describing students' growth, portfolios can help students to think holistically and provide the evaluators (teachers, principals, and others) with records of learning activities.

However, some researchers have also cautioned that certain problems, such as politics, logistics, interpretation, reliability, and validity, could arise, especially if using portfolios as an assessment tool on a large scale (for an overview, see Norris 1996). Terwilliger (1997), in particular, has questioned some claims made by proponents of portfolios. As Terwilliger (1997) has indicated, it is not clear that portfolios are useful assessment devices in all subject matters and at all grade levels, though portfolios may have value as instructional aids.

\subsection{Learning strategy-based instruction}

Learning strategy-based (LSB) instruction is a learner-focused approach to teaching that emphasizes both explicit and implicit integration of language learning strategies in the language classroom, with the goal of creating greater learner autonomy and increased proficiency (Brown 2001; Cohen 1998). Learning strategy-based instruction helps students to become more aware of available strategies, to understand how to organize and use strategies systematically and effectively, and to learn when and how to transfer strategies to new contexts (Brown 2001; Yang 2002). Researchers have suggested a sequence 
of steps to follow when conducting learning strategy-based instruction (e.g., O'Malley and Chamot 1990; Oxford 1990, 1993; Weinstein and Underwood 1985). These general procedures are summarized as follows:

- Diagnosis: Identifying and assessing students' learning strategies through observation, interviews, questionnaires, diaries, or think-aloud procedures.

- Preparation/Awareness-Raising: Developing students' awareness of different strategies; explaining the concept and importance of learning strategies; developing goals for strategy use and affective control for individuals and the entire class.

- Instruction: Providing direct and informed instruction on learning strategies through explanation, modeling, practice, and integration; providing different practice opportunities with varied learning tasks or content.

- Evaluation: Helping students evaluate their own strategy use; evaluating the whole strategy training and revising the training component if necessary.

\section{Linking portfolios to learning strategy-based instruction: Significance of the current study}

There has been little research on the relationship of portfolios to learning strategy-based instruction, and that is why the current study was conducted. As this study demonstrates, portfolios can serve at least three major functions in learning strategy-based instruction. First, portfolios can document the planning, learning, monitoring, and evaluation processes. Second, portfolios can help raise students' awareness about learning strategies and autonomy. Third, through compiling portfolios, learning strategy-based instruction can be reinforced.

\section{Research questions}

This study posed three research questions:

1. What do college students think about the use of portfolios in their EFL class?

2. What are the benefits or problems of using portfolios as tools to enhance learning in an EFL course?

3. Which assessment tool - portfolios or traditional pen-and-paper tests - is more effective in facilitating EFL student learning and autonomy?

\section{Methodology of this study}

\subsection{Participants}

Participants were students enrolled in a freshman English course (with aural/oral training) taught by the researcher. Altogether 42 students participated in the pilot study in 2000, including 27 females and 15 males. Among them, 
$21(50 \%)$ were majoring in law and social sciences, 19 (45\%) were studying in the College of Management, and 2 students were majoring in electronic engineering.

In the first semester of the 2001-2002 academic year, 45 students participated in the formal study. Among these students, $13(29 \%)$ were majoring in law and social sciences and $32(71 \%)$ were studying in the College of Management. There were 36 female and 9 male students.

In the second semester of the 2001-2002 academic year, 36 students, including 28 females and 8 males, participated in the formal study. Of these 36 students, $11(31 \%)$ were law or social science majors, and $25(69 \%)$ were management majors. Basically they are the same group of students as those in the first semester since this course is a two-semester course with normal student attrition and addition. Eleven students dropped out after the first semester and two new students were added in the second semester. There is no significant difference between the two groups.

\subsection{Procedures and schedules}

The researcher conducted the pilot study in 2000-2001 and the formal study in 2001-2002. In both the pilot study and the formal study, portfolios were integrated into the framework and procedures - i.e., diagnosis, preparation, instruction, and evaluation - for learning strategy-based instruction in a freshman English course. The pilot study and the formal study generally followed the same procedures. However, there was one main difference. In the pilot study, when students' reactions were solicited after the portfolio sharing (in mid-semester) and portfolio presentation (at the end of the first and second semesters), openended questions were used. In the formal study, both open-ended and fivepoint, Likert-scaled questions were included in the questionnaires at the times when data were gathered.

The general procedures of integrating portfolios into the learning strategybased instruction are outlined in Appendix A. They are summarized by semester as follows.

5.2.1. First semester. At the beginning of the first semester, for the purpose of diagnosis, an English learning questionnaire was used to assess students' beliefs and learning strategy use, and an English proficiency test was given as a pretest. For preparation, the instructor (researcher) introduced the guidelines (Appendix B) to students on how to prepare a portfolio.

During the semester, portfolios were integrated into learning strategy-based instruction. Activities, such as setting goals, making learning plans, monitoring progress, and understanding learning styles were conducted in class. Midsemester portfolio sharing and students' self-reflection (about plans, progress 
so far, resources to share, and problems and possible solutions) were implemented.

Finally, at the end of the semester, English listening and reading tests were given as a post-test. Portfolio presentation and evaluation (including self-evaluation, peer evaluation, and instructor evaluation) were completed, followed by a course evaluation and portfolio survey.

Below is the first-semester schedule:

a. Specifying the purposes of portfolios, matching the purposes with instructional goals, and integrating portfolios into classroom activities and the students' work and assignments; developing syllabus and course materials (1st month).

b. Introducing the guidelines to students for preparing portfolios (2nd month).

c. Integrating portfolios into class instruction; recording students' progress and performance (3rd-5th month).

d. Arranging for mid-semester portfolio showcase and students' self-reflection; allowing students to look at each other's portfolios to help students understand what makes a good language portfolio (4th month).

e. Allocating time for end-of-semester portfolio presentation and final peer and self-evaluation. Administering first portfolio survey and learning style survey (6th month).

5.2.2. Second semester. To compare the impact of portfolio assessment and traditional assessment (pen-and-paper tests) on students' learning, students were evaluated by both language proficiency tests and a portfolio assessment in the second semester of the 2001-2002 year. Information on students' learning progress and classroom performance was recorded during the semester. Likewise, students were surveyed about their reactions toward these different assessment tools.

The second-semester schedule was as follows:

a. Implementing portfolio assessment and traditional tests according to the course syllabus (7th-10th month).

b. Managing time for end-of-semester portfolio presentation and final peer and self-evaluation.

c. Administering the second portfolio survey on students' reactions toward both assessment tools (11th month).

\subsection{Instruments}

The English learning questionnaire, designed by the researcher (Yang 1992), was used to assess students' beliefs and learning strategy use. It contained three sections. Section 1 contained 35 items from the Beliefs About Language Learning Inventory (BALLI, ESL/EFL version, Horwitz 1987) and one final 
open-ended question for additional beliefs from the students. In this section, the subjects answered on a 5-point scale whether they disagree or agree with the statements. Section 2 contained 49 items of statements adapted from Oxford's Strategy Inventory for Language Learning (SILL, EFL/ESL 7.0 version, Oxford 1989) and one final open-ended question for additional strategy use. This section assessed the frequency with which students used various language learning strategies. The last section intended to obtain students' background information, such as their gender, age, major, their perceived motivation and proficiency in learning English, and experiences of traveling or living in an English-speaking country.

The questionnaire was translated into Chinese, pilot tested, and modified in previous studies (Yang 1992, 1999). Both the BALLI and SILL were found to have content validity and weak, non-significant correlations with the MarlowCrowne Social Desirability Scale (Yang 1992). This means that social desirability response bias (i.e., answering according to what one thinks the researcher wants) is negligible. As assessed earlier, the Chinese BALLI had a Cronbach alpha of 0.69, while the Chinese SILL had a Cronbach alpha of 0.94 for internal-consistency reliability (Yang 1999). In this specific study, internal consistency reliability using Cronbach's alpha, based on the 45 subjects, was 0.69 for the BALLI and 0.92 for the SILL.

The learning style survey (Table 1) was modified from David Nunan's document (Nunan 1995), which focused on students' favored mode of learning (e.g., reading vs. listening, groups vs. alone) and whether the learner preferred selfdirected learning, teacher-directed, or teacher-mediated learning. It contained 25 items. The learning style survey had a Cronbach alpha of 0.72 (43 subjects).

The first portfolio survey (Table 2) used in the formal study contained 32 statements that were mostly composed from previous student reactions to the open-ended questions from the pilot study. The questions assessed students' attitudes and reactions toward the use of portfolios in four areas: (1) actual practice in preparing portfolios (e.g., items 5, 9, 15, 25), (2) advantages and disadvantages of portfolios (e.g., items 3, 8, 10, 11, 12, 16, 18, 22, 23, 26, 27, $28,30,31,32$ ), (3) the portfolio sharing activities (e.g., items 2, 6, 14, 21), (4) perception or understanding about the portfolio (e.g., items 1, 4, 7, 13, 17, 19, $20,24,29)$. In addition, the survey had one open-ended question for additional opinions from the students. In this study, the first portfolio survey's internalconsistency reliability using Cronbach's alpha on 43 subjects was 0.82 .

The second portfolio survey (Table 3) included 19 statements that students rated on a five-point scale from 1 (strongly disagree) to 5 (strongly agree) and three open-ended questions. The questions concerned reactions to the use of portfolios as a learning tool (e.g., items 1, 4, 6, 7, 8, 11, 12; Cronbach's alpha $=0.82$ ) and as an assessment tool (e.g., items 2, 3, 9, 10, 17; Cronbach's alpha $=0.74)$. In this study, Cronbach's alpha coefficient for all items of the second 


\section{$300 \quad$ Nae-Dong Yang}

Table 1. Frequencies of response (in \%), means and standard deviations for the learning style survey items

\begin{tabular}{|c|c|c|c|c|c|c|c|c|}
\hline & Item description $^{\mathrm{a}}$ & $1^{b}$ & 2 & 3 & 4 & 5 & Mean & SD \\
\hline 1. & $\begin{array}{l}\text { I feel embarrassed when } \\
\text { the teacher asks me to } \\
\text { speak in front of other } \\
\text { students. }\end{array}$ & $11.6^{\mathrm{C}}$ & 14.0 & 46.5 & 18.6 & 9.3 & 3.00 & $\overline{1.09}$ \\
\hline 2. & I like to learn by reading & 0 & 2.3 & 14.0 & 48.8 & 34.9 & 4.16 & 0.75 \\
\hline 3. & $\begin{array}{l}\text { I like to learn by } \\
\text { listening to and using } \\
\text { cassettes or CDs. }\end{array}$ & 2.3 & 16.3 & 30.2 & 37.2 & 14.0 & 3.44 & 1.01 \\
\hline 4. & $\begin{array}{l}\text { I like to learn through } \\
\text { games. }\end{array}$ & 4.7 & 11.6 & 30.2 & 16.3 & 37.2 & 3.70 & 1.23 \\
\hline 5. & $\begin{array}{l}\text { I like to write down what } \\
\text { I hear, speak, or read. }\end{array}$ & 7.0 & 23.3 & 60.5 & 9.3 & 0 & 2.72 & 0.73 \\
\hline 6. & $\begin{array}{l}\text { I like the teacher to } \\
\text { explain rules of grammar } \\
\text { to me. }\end{array}$ & 7.0 & 14.0 & 37.2 & 39.5 & 2.3 & 3.16 & 0.95 \\
\hline 7. & $\begin{array}{l}\text { I like to figure out rules } \\
\text { of grammar myself. }\end{array}$ & 9.3 & 11.6 & 51.2 & 25.6 & 2.3 & 3.00 & 0.93 \\
\hline 8. & $\begin{array}{l}\text { I like the teacher to } \\
\text { explain the meaning of } \\
\text { new words. }\end{array}$ & 2.3 & 14.0 & 37.2 & 39.5 & 7.0 & 3.35 & 0.90 \\
\hline 9. & $\begin{array}{l}\text { I like to figure out the } \\
\text { meanings of words by } \\
\text { myself. }\end{array}$ & 0 & 0 & 25.6 & 62.8 & 11.6 & 3.86 & 0.60 \\
\hline 10. & $\begin{array}{l}\text { I like the teacher to tell } \\
\text { me all my mistakes. }\end{array}$ & 2.3 & 4.7 & 34.9 & 46.5 & 11.6 & 3.60 & 0.85 \\
\hline 11. & $\begin{array}{l}\text { I like the teacher to let } \\
\text { me find my own } \\
\text { mistakes. }\end{array}$ & 2.3 & 23.3 & 46.5 & 20.9 & 7.0 & 3.07 & 0.91 \\
\hline 12. & I like to study by myself. & 0 & 11.6 & 23.3 & 39.5 & 25.6 & 3.79 & 0.97 \\
\hline 13. & I like to work in pairs. & 4.7 & 9.3 & 25.6 & 39.5 & 20.9 & 3.63 & 1.07 \\
\hline 14. & $\begin{array}{l}\text { I like to work in small } \\
\text { groups. }\end{array}$ & 4.7 & 4.7 & 18.6 & 46.5 & 25.6 & 3.84 & 1.02 \\
\hline 15. & $\begin{array}{l}\text { I like to work with the } \\
\text { whole class. }\end{array}$ & 7.0 & 0 & 20.9 & 39.5 & 32.6 & 3.91 & 1.09 \\
\hline 16. & $\begin{array}{l}\text { I like to practice outside } \\
\text { of the classroom. }\end{array}$ & 0 & 2.3 & 25.6 & 44.2 & 27.9 & 3.98 & 0.80 \\
\hline 17. & $\begin{array}{l}\text { I like to be part of the } \\
\text { decision-making process } \\
\text { about what we will learn } \\
\text { (that is, the content of } \\
\text { the lessons). }\end{array}$ & 4.7 & 4.7 & 16.3 & 53.5 & 20.9 & 3.81 & 0.98 \\
\hline
\end{tabular}


Table 1 (cont.). Frequencies of response (in \%), means and standard deviations for the learning style survey items

\begin{tabular}{|c|c|c|c|c|c|c|c|c|}
\hline & Item description $^{\mathrm{a}}$ & $1^{b}$ & 2 & 3 & 4 & 5 & Mean & SD \\
\hline 18. & $\begin{array}{l}\text { I like the teacher to make } \\
\text { all the decisions about } \\
\text { what we will learn (that } \\
\text { is, the content of the } \\
\text { lessons). }\end{array}$ & 4.7 & 32.6 & 51.2 & 7.0 & 4.7 & 2.74 & 0.85 \\
\hline 19. & $\begin{array}{l}\text { I like to be part of the } \\
\text { decision-making process } \\
\text { about how we will learn } \\
\text { (that is, the classroom } \\
\text { tasks and activities we } \\
\text { will take part in). }\end{array}$ & 2.3 & 2.3 & 20.9 & 41.9 & 32.6 & 4.00 & 0.93 \\
\hline 20. & $\begin{array}{l}\text { I like the teacher to make } \\
\text { all the decisions about } \\
\text { how we will learn (that } \\
\text { is, the classroom tasks } \\
\text { and activities we will } \\
\text { take part in). }\end{array}$ & 2.3 & 25.6 & 53.5 & 14.0 & 4.7 & 2.93 & 0.83 \\
\hline 21. & $\begin{array}{l}\text { I like to be responsible } \\
\text { for my own learning. }\end{array}$ & 0 & 0 & 14.0 & 53.5 & 32.6 & 4.19 & 0.66 \\
\hline 22. & $\begin{array}{l}\text { I like the teacher to } \\
\text { explain the objectives of } \\
\text { the course to me. }\end{array}$ & 2.3 & 7.0 & 16.3 & 55.8 & 18.6 & 3.81 & 0.91 \\
\hline 23. & $\begin{array}{l}\text { I like the teacher to give } \\
\text { reasons for what we are } \\
\text { learning and how we are } \\
\text { learning. }\end{array}$ & 2.3 & 9.3 & 20.9 & 48.8 & 18.6 & 3.72 & 0.96 \\
\hline 24. & $\begin{array}{l}\text { I like to assess my own } \\
\text { progress. }\end{array}$ & 2.3 & 4.7 & 30.2 & 51.2 & 11.6 & 3.65 & 0.84 \\
\hline 25. & $\begin{array}{l}\text { I like the teacher to } \\
\text { assess my progress for } \\
\text { me. }\end{array}$ & 2.3 & 20.9 & 58.1 & 14.0 & 4.7 & 2.98 & 0.80 \\
\hline
\end{tabular}

Note: The learning style survey's internal-consistency reliability using Cronbach's alpha on 43 subjects in this study was 0.72 .

a The survey was administered in Chinese and the items presented here were modified from David Nunan's English version (1995).

b 1 = Strongly disagree, $2=$ Disagree, $3=$ Neutral, $4=$ Agree, and $5=$ Strongly agree .

$\mathrm{c}$ The percentage has been rounded. 


\section{Nae-Dong Yang}

Table 2. Frequencies of response (in \%), means and standard deviations for the first portfolio survey items

\begin{tabular}{|c|c|c|c|c|c|c|c|c|}
\hline & Item description $^{\mathrm{a}}$ & $1^{\mathrm{b}}$ & 2 & 3 & 4 & 5 & Mean & SD \\
\hline 1. & $\begin{array}{l}\text { Compiling a portfolio } \\
\text { requires a clear } \\
\text { organizing concept. }\end{array}$ & $0^{c c}$ & 2.3 & 7.0 & 60. & 30.23 & 4.19 & $\overline{0.66}$ \\
\hline 2. & $\begin{array}{l}\text { The portfolio sharing } \\
\text { activities offered me } \\
\text { chances to learn good } \\
\text { English learning } \\
\text { methods from other } \\
\text { classmates. }\end{array}$ & 0 & 0 & 0 & 2.3 & 97.7 & 4.98 & 0.15 \\
\hline 3. & $\begin{array}{l}\text { It takes me a lot of time } \\
\text { to compile the portfolio. }\end{array}$ & 0 & 2.3 & 9.3 & 58.1 & 30.2 & 4.16 & 0.69 \\
\hline 4. & $\begin{array}{l}\text { I feel the appearance of } \\
\text { the portfolio (including } \\
\text { its cover and art design) } \\
\text { is important. }\end{array}$ & 4.7 & 9.3 & 30.2 & 46.5 & 9.3 & 3.47 & 0.96 \\
\hline 5. & $\begin{array}{l}\text { I reflected on and } \\
\text { evaluated my learning in } \\
\text { each aspect when } \\
\text { compiling the portfolio. }\end{array}$ & 2.3 & 2.3 & 14.0 & 55.8 & 25.6 & 4.00 & 0.85 \\
\hline 6. & $\begin{array}{l}\text { During the portfolio } \\
\text { sharing activities, I was } \\
\text { able to share useful } \\
\text { English learning } \\
\text { resources with my } \\
\text { classmates. }\end{array}$ & 2.3 & 0 & 14.0 & 60.5 & 23.3 & 4.02 & 0.77 \\
\hline 7. & $\begin{array}{l}\text { I have a clear concept } \\
\text { about how to compile a } \\
\text { portfolio. }\end{array}$ & 2.3 & 2.3 & 58.1 & 25.6 & 11.6 & 3.42 & 0.82 \\
\hline 8. & $\begin{array}{l}\text { The portfolio helped me } \\
\text { organize and arrange my } \\
\text { English learning. }\end{array}$ & 2.3 & 7.0 & 27.9 & 48.8 & 14.0 & 3.65 & 0.90 \\
\hline 9. & $\begin{array}{l}\text { I have completed most of } \\
\text { the learning goals I set } \\
\text { up in my portfolio. }\end{array}$ & 4.7 & 20.9 & 44.2 & 30.2 & 0 & 3.00 & 0.85 \\
\hline 10. & $\begin{array}{l}\text { The portfolio increased } \\
\text { the burden of my study. }\end{array}$ & 2.3 & 11.6 & 41.9 & 37.2 & 7.0 & 3.35 & 0.87 \\
\hline
\end{tabular}


Table 2 (cont.). Frequencies of response (in \%), means and standard deviations for the first portfolio survey items

\begin{tabular}{|c|c|c|c|c|c|c|c|c|}
\hline & Item description $^{\mathrm{a}}$ & $1^{b}$ & 2 & 3 & 4 & 5 & Mean & SD \\
\hline$\overline{11 .}$ & $\begin{array}{l}\text { The portfolio allowed } \\
\text { me to choose what I like } \\
\text { to read or listen to } \\
\text { according to my personal } \\
\text { interests. }\end{array}$ & 0 & 0 & 4.7 & 53.5 & 41.9 & 4.37 & $\overline{0.58}$ \\
\hline 12. & $\begin{array}{l}\text { The portfolio increased } \\
\text { my willingness to learn } \\
\text { actively. }\end{array}$ & 2.3 & 2.3 & 39.5 & 34.9 & 20.9 & 3.70 & 0.91 \\
\hline 13. & $\begin{array}{l}\text { I feel the content of the } \\
\text { portfolio (including its } \\
\text { organization and details) } \\
\text { is important. }\end{array}$ & 4.7 & 2.3 & 11.6 & 39.5 & 41.9 & 4.12 & 1.03 \\
\hline 14. & $\begin{array}{l}\text { Portfolio sharing can } \\
\text { increase classmates' } \\
\text { cooperative learning and } \\
\text { mutual growth in } \\
\text { English. }\end{array}$ & 2.3 & 2.3 & 9.3 & 48.8 & 37.2 & 4.16 & 0.87 \\
\hline 15. & $\begin{array}{l}\text { The goal I originally set } \\
\text { up in the portfolio was } \\
\text { too difficult and I } \\
\text { couldn't reach it. }\end{array}$ & 2.3 & 20.9 & 39.5 & 27.9 & 9.3 & 3.21 & 0.97 \\
\hline 16. & $\begin{array}{l}\text { The portfolio allowed } \\
\text { me to choose how to } \\
\text { plan and learn my } \\
\text { English according to my } \\
\text { learning style. }\end{array}$ & 2.3 & 0 & 4.7 & 62.8 & 30.2 & 4.19 & 0.73 \\
\hline 17. & $\begin{array}{l}\text { Preparing a portfolio } \\
\text { requires good computer } \\
\text { skills and artistic talent. }\end{array}$ & 4.7 & 11.6 & 48.8 & 23.3 & 11.6 & 3.26 & 0.98 \\
\hline 18. & $\begin{array}{l}\text { The portfolio helped me } \\
\text { understand my strengths } \\
\text { and weaknesses in } \\
\text { English. }\end{array}$ & 2.3 & 4.7 & 11.6 & 69.8 & 11.6 & 3.84 & 0.78 \\
\hline 19. & $\begin{array}{l}\text { I think reflection and } \\
\text { self-evaluation is the } \\
\text { most important part of } \\
\text { the portfolio. }\end{array}$ & 2.3 & 7.0 & 14.0 & 46.5 & 30.2 & 3.95 & 0.97 \\
\hline 20. & $\begin{array}{l}\text { The handout's } \\
\text { introduction to the } \\
\text { portfolio was not clear } \\
\text { enough. }\end{array}$ & 16.3 & 39.5 & 34.9 & 9.3 & 0 & 2.37 & 0.87 \\
\hline
\end{tabular}




\section{Nae-Dong Yang}

Table 2 (cont.). Frequencies of response (in \%), means and standard deviations for the first portfolio survey items

\begin{tabular}{|c|c|c|c|c|c|c|c|c|}
\hline & Item description $^{\mathrm{a}}$ & $1^{b}$ & 2 & 3 & 4 & 5 & Mean & SD \\
\hline 21. & $\begin{array}{l}\text { The portfolio sharing } \\
\text { activities were helpful to } \\
\text { my understanding of the } \\
\text { portfolio. }\end{array}$ & 2.3 & 2.3 & 2.3 & 69.8 & 23.3 & 4.09 & $\overline{0.75}$ \\
\hline 22. & $\begin{array}{l}\text { The portfolio will be of } \\
\text { great help to my future } \\
\text { independent learning. }\end{array}$ & 2.3 & 7.0 & 27.9 & 48.8 & 14.0 & 3.65 & 0.90 \\
\hline 23. & $\begin{array}{l}\text { I feel some practices } \\
\text { (like listening or } \\
\text { speaking) could not be } \\
\text { easily presented in the } \\
\text { portfolio. }\end{array}$ & 0 & 4.7 & 11.6 & 60.5 & 23.3 & 4.02 & 0.74 \\
\hline 24. & $\begin{array}{l}\text { Looking at previous } \\
\text { students' portfolio } \\
\text { samples gave me a better } \\
\text { idea about portfolios. }\end{array}$ & 2.3 & 4.7 & 37.2 & 37.2 & 18.6 & 3.65 & 0.92 \\
\hline 25. & $\begin{array}{l}\text { I added appropriate } \\
\text { explanations to the } \\
\text { samples or records, } \\
\text { which I included in the } \\
\text { portfolio. }\end{array}$ & 2.3 & 9.3 & 20.9 & 51.2 & 16.3 & 3.70 & 0.94 \\
\hline 26. & $\begin{array}{l}\text { I feel the portfolio can } \\
\text { present my learning } \\
\text { results. }\end{array}$ & 4.7 & 4.7 & 30.2 & 51.2 & 9.3 & 3.56 & 0.91 \\
\hline 27. & $\begin{array}{l}\text { The portfolio made me } \\
\text { realize that I can learn } \\
\text { anytime and anywhere, } \\
\text { not just in the classroom. }\end{array}$ & 0 & 0 & 9.3 & 55.8 & 34.9 & 4.26 & 0.62 \\
\hline 28. & $\begin{array}{l}\text { Portfolios can show my } \\
\text { efforts in learning } \\
\text { English outside of the } \\
\text { classroom. }\end{array}$ & 0 & 2.3 & 16.3 & 51.2 & 30.2 & 4.09 & 0.75 \\
\hline 29. & $\begin{array}{l}\text { I still don't understand } \\
\text { why we needed to } \\
\text { compile a portfolio. }\end{array}$ & 32.6 & 48.9 & 7.0 & 9.3 & 2.3 & 2.00 & 1.00 \\
\hline 30. & $\begin{array}{l}\text { When compiling the } \\
\text { portfolio, I had a chance } \\
\text { to reflect on my English } \\
\text { learning of this semester. }\end{array}$ & 2.3 & 2.3 & 7.0 & 62.8 & 25.6 & 4.07 & 0.80 \\
\hline 31. & $\begin{array}{l}\text { I feel the portfolio is not } \\
\text { helpful to my learning. }\end{array}$ & 18.6 & 60.5 & 16.3 & 2.3 & 2.3 & 2.09 & 0.81 \\
\hline
\end{tabular}


Table 2 (cont.). Frequencies of response (in \%), means and standard deviations for the first portfolio survey items

\begin{tabular}{llccccccc}
\hline & Item description $^{\mathrm{a}}$ & $1^{\mathrm{b}}$ & 2 & 3 & 4 & 5 & Mean & SD \\
\hline 32. & $\begin{array}{l}\text { The portfolio helps me } \\
\text { to keep the habit of } \\
\text { listening to, reading, or } \\
\text { writing English } \\
\text { regularly. }\end{array}$ & 2.3 & 18.6 & 44.2 & 25.6 & 9.3 & 3.21 & 0.94 \\
& & & & & & & \\
\hline
\end{tabular}

Note: The first portfolio survey's internal-consistency reliability using Cronbach's alpha on 43 subjects in this study was 0.82 .

a The survey was administered in Chinese and the item description presented here was translated from Chinese into English by the researcher.

b 1 = Strongly disagree, 2 = Disagree, $3=$ Neutral, $4=$ Agree, and $5=$ Strongly agree .

c The percentage has been rounded.

Table 3. Frequencies of response (in \%), means and standard deviationsfor the second portfolio survey items

\begin{tabular}{|c|c|c|c|c|c|c|c|c|}
\hline & Item description $^{\mathrm{a}}$ & $1^{b}$ & 2 & 3 & 4 & 5 & Mean & SD \\
\hline 1. & $\begin{array}{l}\text { The portfolio helped me } \\
\text { organize learning in this } \\
\text { course. }\end{array}$ & $0^{\mathrm{c}}$ & 0 & 14.3 & 68.6 & 17.1 & 4.03 & $\overline{0.57}$ \\
\hline 2. & $\begin{array}{l}\text { The portfolio is a good } \\
\text { tool to show my learning } \\
\text { process. }\end{array}$ & 2.9 & 0 & 14.3 & 71.4 & 11.4 & 3.89 & 0.72 \\
\hline 3. & $\begin{array}{l}\text { The portfolio represents } \\
\text { my learning results in } \\
\text { this course. }\end{array}$ & 0 & 5.7 & 11.4 & 74.3 & 8.6 & 3.86 & 0.65 \\
\hline 4. & $\begin{array}{l}\text { The portfolio helped me } \\
\text { to reflect on my learning } \\
\text { in this course. }\end{array}$ & 0 & 0 & 8.6 & 68.6 & 22.9 & 4.14 & 0.55 \\
\hline 5. & $\begin{array}{l}\text { The portfolio increased } \\
\text { the interaction between } \\
\text { students and the } \\
\text { instructor. }\end{array}$ & 0 & 8.6 & 34.3 & 40.0 & 17.1 & 3.66 & 0.87 \\
\hline 6. & $\begin{array}{l}\text { The portfolio is a good } \\
\text { tool to help students } \\
\text { learn. }\end{array}$ & 0 & 2.9 & 28.6 & 60.0 & 8.6 & 3.74 & 0.66 \\
\hline 7. & $\begin{array}{l}\text { The portfolio provides a } \\
\text { multi-dimensional } \\
\text { perspective about } \\
\text { learning. }\end{array}$ & 0 & 2.9 & 5.7 & 65.7 & 25.7 & 4.14 & 0.65 \\
\hline
\end{tabular}




\section{Nae-Dong Yang}

Table 3 (cont.). Frequencies of response (in \%), means and standard deviationsfor the second portfolio survey items

\begin{tabular}{|c|c|c|c|c|c|c|c|c|}
\hline & Item description $^{\mathrm{a}}$ & $1^{\mathrm{b}}$ & 2 & 3 & 4 & 5 & Mean & SD \\
\hline 8. & $\begin{array}{l}\text { The portfolio will help } \\
\text { my learning in future } \\
\text { courses. }\end{array}$ & 0 & 11.4 & 42.9 & 37.1 & 8.6 & 3.43 & 0.81 \\
\hline 9. & $\begin{array}{l}\text { The portfolio is a good } \\
\text { tool to evaluate students' } \\
\text { performance. }\end{array}$ & 5.7 & 2.9 & 34.3 & 40.0 & 17.1 & 3.60 & 1.01 \\
\hline 10. & $\begin{array}{l}\text { The portfolio provides a } \\
\text { multi-dimensional } \\
\text { perspective about } \\
\text { evaluation. }\end{array}$ & 0 & 2.9 & 8.6 & 68.6 & 20.0 & 4.06 & 0.64 \\
\hline 11. & $\begin{array}{l}\text { The portfolio helps my } \\
\text { future independent } \\
\text { learning. }\end{array}$ & 0 & 5.7 & 17.1 & 60.0 & 17.1 & 3.89 & 0.76 \\
\hline 12. & $\begin{array}{l}\text { My experience of } \\
\text { learning through a } \\
\text { portfolio in this course } \\
\text { has been successful. }\end{array}$ & 2.9 & 0 & 45.7 & 42.9 & 8.6 & 3.54 & 0.78 \\
\hline 13. & $\begin{array}{l}\text { It has been successful to } \\
\text { use portfolios for } \\
\text { teaching and evaluation } \\
\text { in this course. }\end{array}$ & 0 & 2.9 & 22.9 & 60.0 & 11.4 & 3.82 & 0.67 \\
\hline 14. & $\begin{array}{l}\text { I will use portfolios in } \\
\text { my future learning. }\end{array}$ & 0 & 14.3 & 45.7 & 37.1 & 2.9 & 3.29 & 0.75 \\
\hline 15. & $\begin{array}{l}\text { I like to assess my own } \\
\text { progress. }\end{array}$ & 0 & 8.6 & 22.9 & 57.1 & 11.4 & 3.71 & 0.79 \\
\hline 16. & $\begin{array}{l}\text { I like the teacher to } \\
\text { assess my progress for } \\
\text { me. }\end{array}$ & 0 & 11.4 & 45.7 & 40.0 & 2.9 & 3.34 & 0.73 \\
\hline 17. & $\begin{array}{l}\text { I prefer to be evaluated } \\
\text { by portfolios. }\end{array}$ & 0 & 8.6 & 40.0 & 48.6 & 2.9 & 3.46 & 0.70 \\
\hline 18. & $\begin{array}{l}\text { I prefer to be evaluated } \\
\text { by paper-and-pencil } \\
\text { tests. }\end{array}$ & 5.7 & 17.1 & 54.3 & 22.9 & 0 & 2.94 & 0.80 \\
\hline 19. & $\begin{array}{l}\text { I think we should use } \\
\text { multiple evaluation } \\
\text { methods }\end{array}$ & 0 & 0 & 5.7 & 60.0 & 34.3 & 4.29 & 0.57 \\
\hline 20. & $\begin{array}{l}\text { According to your } \\
\text { experience, what are the } \\
\text { advantages of using } \\
\text { portfolios? }\end{array}$ & & & & & & & \\
\hline
\end{tabular}


Table 3 (cont.). Frequencies of response (in \%), means and standard deviationsfor the second portfolio survey items

\begin{tabular}{|c|c|c|c|c|c|c|c|c|}
\hline & Item description $^{\mathrm{a}}$ & $1^{b}$ & 2 & 3 & 4 & 5 & Mean & SD \\
\hline 21. & $\begin{array}{l}\text { According to your } \\
\text { experience, what are the } \\
\text { disadvantages of using } \\
\text { portfolios? }\end{array}$ & & & & & & & \\
\hline 22. & $\begin{array}{l}\text { Please compare } \\
\text { traditional } \\
\text { pen-and-paper tests (e.g., } \\
\text { class quizzes, and GEPT } \\
\text { tests) with portfolio } \\
\text { assessment (including } \\
\text { self-evaluation, peer } \\
\text { evaluation, and } \\
\text { instructor's evaluation). } \\
\text { In your opinion, which } \\
\text { one is better? Why? }\end{array}$ & & & & & & & \\
\hline
\end{tabular}

Note: The second portfolio survey's internal-consistency reliability using Cronbach's alpha on 35 subjects in this study was 0.81 .

a The survey was administered in Chinese and the item description presented here was translated from Chinese into English by the researcher.

b 1 = Strongly disagree, 2 = Disagree, $3=$ Neutral, $4=$ Agree, and $5=$ Strongly agree. c The percentage has been rounded.

portfolio survey computed on 35 subjects was 0.81 . As for the first and the second open-ended questions, students were asked their opinions about the advantages and disadvantages of using portfolios. The third question asked students to compare which assessment tool - portfolio or traditional pen-and-paper tests - is better and to explain their reasons. This questionnaire was administered to students at the end of the 2001-2002 academic year.

The study used two listening and reading tests from the General English Proficiency Test (high-intermediate level) for the pretests and post-tests. The General English Proficiency Test was developed by the Language Training and Testing Center in Taiwan and has reported high reliability and validity. Though the pre- and post listening test (listening test 1 and 3 ) were the same, there was a nine-month interval between the two tests. The General English Proficiency Test considers scores above 80 to be a passing score. 


\section{Results and discussion}

\subsection{Results of the English learning questionnaire}

According to the questionnaire results, these students reported using compensation strategies most frequently and memory strategies least frequently, similar to the profile of previous students taking the course (Yang 1996). These students believed that English is an important tool for study, important to their future careers and that they could learn English well. They stressed the importance of good pronunciation and frequent practice.

Such information was helpful to the instructor (researcher), since students' beliefs could be taken into consideration when planning lessons, while students' strategy profiles made it easy to adopt materials or mini-lessons developed previously for learning strategy-based instruction in this portfolio study. Besides, students could use this information about their learning strategy use to assist them in setting learning goals and planning their study. During the semester, they could also use portfolios to monitor and record their general learning process as well as specific strategy use.

\subsection{Results of the learning style survey}

Most of the responses to the learning style survey (see Table 1) were in the neutral range or slightly positive, indicating that there was no single learning style profile for the whole group. However, some items stood out as having clear agreement: S2, "I like to learn by reading" (mean $=4.16$ out of a possible 5); S19, "I like to be part of the decision-making process about how we will learn" (mean $=4.00$ ), and S21, "I like to be responsible for my own learning" $($ mean $=4.19)$.

\subsection{Students' reactions to the use of portfolios}

According to the final portfolio survey in the pilot study of fall 2000, among the 30 students who answered the open-ended survey anonymously, most students felt positive about the experience of compiling portfolios in their freshman English class. They reported that in order to prepare the portfolios, they had to continuously keep contact with the language they were learning by listening and reading in daily life. "A daily language learning habit" was what they got from preparing their portfolios. One student wrote "I got the habit of listening to English every day." Another wrote "I can make use of possible opportunities to learn English in daily life." In the opinion of these students, the portfolio experience also helped them to extend their learning approach and explore new learning materials from the Internet, newspaper, or magazines, instead of just

limiting themselves to learning in the classroom or from textbooks. They were able to select their favorite topics for in-depth learning or work on their weakest 
areas. From the portfolio preparation, they also learned how to collect, organize, and present information. At the same time, they were able to reflect on their own learning results and check on their progress. One student wrote that the portfolio helped her "know what [she] had done in this semester." Another commented that "It is a really good way to check learning." To sum up, $80 \%$ of these students wanted to continue using portfolios the next semester, because they felt that the portfolios offered them direction and chances for learning.

Students also had positive reactions to the use of portfolios in the English class in the formal study of 2001-2002 (see first portfolio survey, Table 2). Ninety-five percent of the students agreed or strongly agreed that the portfolio allowed them to choose what they like to read or listen to according to their personal interests. The portfolios also let them plan how to learn English according to their learning styles (93\%), and they made them realize that they could learn anytime and anywhere, not just in the classroom (90\%). In addition, the second portfolio survey in 2001-2002 also revealed students' positive feeling about using portfolios as a learning tool (see Table 3). Over $90 \%$ of the students agreed or strongly agreed that the portfolios provided a multidimensional perspective about learning, and that the portfolios helped them reflect on learning $(91 \%)$ and organize their learning (86\%). Above all, over $70 \%$ of these students found it successful to use portfolios for instruction and evaluation in this course.

Most students found the portfolio sharing activities very helpful. Over $80 \%$ of the students reported that the portfolio-sharing activities offered them chances to develop useful English learning methods from other classmates, increased classmates' cooperative learning and mutual growth in English proficiency, let them share useful English learning resources with their classmates, and helped them understand a variety of learning processes. More details are provided in Table 2 .

\subsection{Advantages and disadvantages of using portfolios as a learning tool}

According to students' answers to the open-ended questions in the pilot study as well as in the second portfolio survey (see Table 3 ) of the formal study, the advantages of using portfolios included promoting the use of metacognitive strategies (e.g., managing and organizing learning, monitoring and observing one's learning, reflecting on one's learning); motivating and enhancing active, multi-dimensional learning; being helpful to future independent learning; facilitating interaction among the instructor and students; showing learning process and progress; presenting learning results; providing a sense of achievement; and practicing presentation skills.

Students' comments about disadvantages included "It takes a lot of time", "It is too much trouble, a burden to prepare", "Some students may complete it 
in a short time and cheat on some samples or fake the records", "Some learning results and methods are hard to present", and "Some learning processes may not be easily recorded".

When asked what problems or difficulties they had encountered when preparing the portfolio, these students listed several personal or technological difficulties. They are categorized as follows: (1) time management (in studying and preparation); (2) learning attitudes (e.g., laziness, procrastination, and lack of determination); (3) problems in record keeping (e.g., some students did not keep good records, some learning could not be recorded easily, or some didn't know how to record or just forgot to record); (4) information management (e.g., how to select and organize work); and (5) other computer-related and access problems.

\subsection{Students' learning style preferences in relation to portfolio use}

Pearson correlations were computed between items on the learning style survey (S1 to S25, Table 1) and items on the first portfolio survey (P1 to P32, Table 2). Numerous significant correlations were found between students' learning style preferences and portfolios. Among the most interesting are the following. Students who liked to write down what they hear, speak, or read (S5) felt positive that the portfolio helped them organize and arrange their English learning $(\mathrm{P} 8), \mathrm{r}=.54, \mathrm{p}<.001$, and believed that portfolio sharing increased cooperative learning and mutual growth in English (P14), $\mathrm{r}=.48, \mathrm{p}<.001$. Those who liked to work in pairs (S13) or small groups (S14) were likely to agree that portfolio sharing could increase classmates' cooperative learning and mutual growth in English (P14), $\mathrm{r}=.55, \mathrm{p}<.001$ and $\mathrm{r}=.49, \mathrm{p}<.001$, respectively. Students who liked to work in small groups (S14) or with the whole class (S15) tended to agree that they reflected on and evaluated their learning in each aspect when compiling the portfolios ( $\mathrm{P} 5), \mathrm{r}=.69, \mathrm{p}<.001$ and $\mathrm{r}=.62$, respectively. That is probably why they also agreed that, by self-reflection and selfevaluation, portfolios helped them understand their strengths and weaknesses $(\mathrm{P} 18), \mathrm{r}=.56$ and $\mathrm{r}=.62, \mathrm{p}<.001$, respectively.

Students who liked to practice English outside of the classroom (S16) tended to agree that through portfolios they could learn anytime and anywhere (P27), $\mathrm{r}=.40, \mathrm{p}<.01$. The portfolios demonstrated their efforts accordingly.

Students who liked to assess their own progress (S24) tended to agree that portfolios helped them learn English according to their learning styles (P16), $\mathrm{r}=.49$; organize and arrange their learning (P8), $\mathrm{r}=.62$; reflect on learning $(\mathrm{P} 30), \mathrm{r}=.57$; understand their strengths and weaknesses $(\mathrm{P} 18), \mathrm{r}=.60$; share useful English learning resources with classmates (P6), $r=.60$; , and keep the habit of reading or listening regularly (P32), $\mathrm{r}=.49$; all $\mathrm{p}<.001$. These same students felt that they had a clear concept of how to compile a portfolio (P7), r= 
.49; that portfolios increased cooperative learning $(\mathrm{P} 14), \mathrm{r}=.50$; that portfolio sharing was helpful $(\mathrm{P} 21), \mathrm{r}=.54$; and that reflection and self-evaluation were the most important parts of portfolio use (P19), $\mathrm{r}=.53$; all $\mathrm{p}<.001$.

Even those students who liked the teacher to assess their progress (S25) tended to agree that when compiling the portfolio, they had a chance to reflect on their English learning of this semester (P30), $\mathrm{r}=.49, \mathrm{p}<.001$. Students who liked the teacher to explain the objectives of the course (S22) also felt positive about the helpfulness of the portfolio to their learning (P22, P30), r $=.50$ and $\mathrm{r}=.55$, respectively, both $\mathrm{p}<.001$, and disagreed with the statement that portfolios were not helpful (P31), $\mathrm{r}=-.50, \mathrm{p}<.001$.

\subsection{Proficiency test results}

The results of the students' pretest and post-test on the General English Proficiency Test are presented in the table in Appendix C. With 80 as a passing score, over $90 \%$ of these students passed the reading pretest, while only $50 \%$ passed the listening pretest. After two semesters of learning strategy-based instruction, students made progress in their listening to a passing rate of over $80 \%$. In fact, paired t-tests revealed that these students' listening post-test results were significantly different from their listening pretest results $(t=-6.64$, $\mathrm{df}=33, \mathrm{p}<0.0005)$.

\subsection{Students' reactions to using portfolios for evaluation}

When students were asked to compare portfolios as an assessment tool to traditional pen-and-paper tests, over one half $(51 \%)$ of the students responded that they would prefer to be evaluated by portfolios, while only $23 \%$ preferred to be evaluated by paper-and-pencil tests. It may be due to the fact that portfolios offered them chances for self-evaluation because over two-thirds (69\%) of the students responded that they liked to assess their own progress. Many (89\%) agreed that the portfolio provided a multi-dimensional perspective to evaluation. The majority (94\%) also agreed that multiple evaluations should be used. In summary, this study, similar to prior reports in the literature (e.g., Paulson, Paulson, and Meyer 1991; Yueh 1999), found that portfolios operated very differently from ordinary paper-and-pencil tests and that students valued portfolio use.

\section{Caveats and suggestions}

The integration of portfolios into learning strategy-based instruction, student work, and student assessment needs careful planning. In addition, there needs

to be time to prepare for evaluation, which may include assembling the finished portfolios, arranging portfolio presentation and peer evaluation, and completing the final evaluation by the instructor. 


\section{Nae-Dong Yang}

To integrate portfolios into English courses, teachers should: (1) introduce the concepts of autonomous learning to students; (2) develop mini-lessons and provide guidelines to help students develop their portfolios; (3) implement frequent portfolio sharing and checking; (4) allocate adequate class time for assembling the portfolios; (5) encourage students to include more than one type of material in the portfolio; and (6) consider other media instead of paper for portfolios.

\section{Conclusions}

Although the challenge to integrate portfolios into learning strategy-based instruction and to facilitate students' autonomous learning is not an easy one, the benefits for both the teacher and students are great. In this study, students generally had positive reactions toward using the portfolio in the class for learning and assessment. Over one half (51\%) agreed that their experience of learning through portfolios was successful. Fewer than $3 \%$ thought that using portfolios was very unsuccessful. Only $5 \%$ felt portfolios were not helpful to their learning.

The recent development of Web-based learning provides a promising autonomous learning environment in which learning strategy-based instruction may play an important role. Future studies might incorporate learning strategybased instruction with Web-based or on-line language learning with portfolios as an important learning tool. Some of the problems encountered, such as difficulty in record keeping, might be improved through computer-assisted or Web-based learning. To conclude, portfolios are a good tool that helps raise students' awareness about learning strategies, facilitate their learning process, and enhance their self-directed learning.

National Taiwan University <naedong@ccms.ntu.edu.tw> 


\section{Appendix A}

Chart for the general procedure of integrating portfolios into learning strategybased instruction

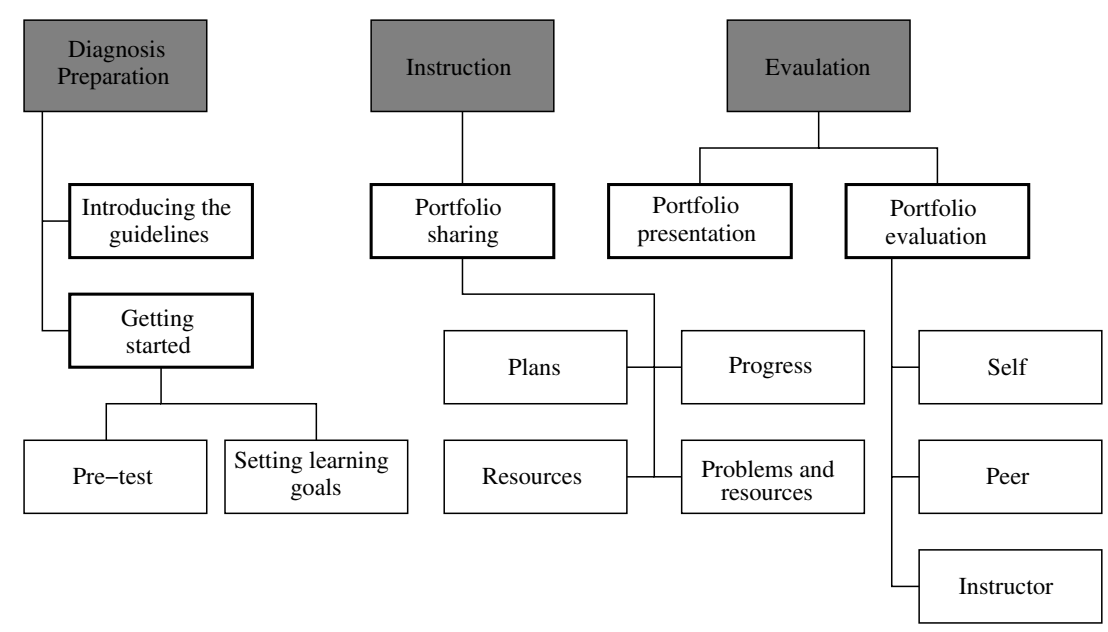

\section{Appendix B}

Guidelines to preparing an English portfolio

(Handout for students, Fall 2001, adapted from McNamara and Deane 1998)

\section{Objectives}

- To reflect on the progress you made in an English course.

- To assess strengths and weaknesses in learning English.

- To establish goals and plans for future independent learning.

\section{General guidelines}

- Go over all the work you did during the week or month and decide which activities (either course work or learning experiences outside class) were the most meaningful to you and from which you learned the most. Think about your learning and keep a learning journal every week or every month.

- Choose one or two representative samples of your work during the period that shows your ability to use English in any of the four skill areas: listening, reading, writing, or speaking.

- For each piece of evidence that you include, please prepare a brief written explanation of what the sample shows about your progress and development as a user of English - in other words, how the sample is significant to your 
development in English. This written explanation is the cover sheet that introduces the evidence that you are presenting in your portfolio.

- As part of the portfolio, please write a letter to the instructor, describing:

○ how much you have completed your plans for improving your weakest area or increasing your skills in English,

$\circ$ the area in which you made the most progress this semester and the reason you improved so much,

$\circ$ any new area of English in which you feel you need further improvement,

$\circ$ an assessment of your effort in the class this semester,

$\circ$ the grade you would give yourself for the portfolio, and

$\circ$ anything you feel like telling the instructor.

- As a final organizing step, please prepare a table of contents and a cover sheet for each section of your portfolio. Present the portfolio materials in a folder or binder with a clear index system.

- Portfolio sharing: There will be two opportunities for you to share your portfolio with other classmates during the semester. Details will be announced later.

\section{The content of the portfolio}

The materials in the portfolio can be direct or indirect evidence of your use of English. Examples of direct evidence are your reading portfolios, vocabulary logs you kept, weekly listening logs, weekly learning journals, news story summaries, free journal writings, any reactions you posted on the course website, the preparation materials for an oral report, a script of a role play, and a photo of the presentation you participated in. An example of indirect evidence is a short written description of a time you used English (e.g., a telephone call, a conversation with an American friend, an e-mail with a Canadian pen pal).

\section{Assessment criteria for the English portfolio}

The portfolios will be read holistically with the three criteria below in mind, and you may use the following questions as references when preparing the portfolio. The portfolio makes up $20 \%$ of your final grade.

1. Have you included all the required materials in the portfolio? That is, (1) learning journals and reflections; (2) representative samples of your work during the semester in listening, reading, writing, speaking, and vocabulary; (3) a written explanation (cover sheet) for each sample describing its significance to your progress in learning English; and (4) a letter to the instructor describing your progress this semester, strong and weak areas, your plan for improving weak areas, and a self-assessment of work during the semester? 
2. Do the representative samples and the written explanations demonstrate your progress in learning English this semester?

3. Does the portfolio show evidence of your thoughtful reflection on the material and activities of the course and careful assessment of progress and learning in the course?

Your self-evaluation and peer evaluation count $3 \%$ each.

\section{Additional notes}

- Learning journals may include the reflective writing you complete at regular intervals (e.g., every week, every two weeks, or every month) and the reflections you write at the end of English classes as required by the instructor or by yourself.

- Samples of reading report sheets, weekly listening logs, news story summaries, and vocabulary logs will be provided for reference. You may design the format of your reading report sheet, weekly listening log, news story summary, and vocabulary log based on your needs and purposes.

- Free journal writing focuses on honest and meaningful communication you make with your classmates and the instructor on the course website. The emphasis is on content and interaction, but you should also pay attention to the correctness of your spelling and sentence structures. You write and share about what you think and feel about the reading selection. More details will be posted on the course website.

\section{Appendix C}

Results of students' English pretest and post-test

\begin{tabular}{llllll}
\hline & $\begin{array}{l}\text { Pretest: } \\
\text { Listening } \\
\text { test 1 }\end{array}$ & $\begin{array}{l}\text { Pretest: } \\
\text { Reading } \\
\text { test 1 } \\
(2001 / 9)\end{array}$ & $\begin{array}{l}\text { Listening } \\
\text { test 2 } \\
(2002 / 3)\end{array}$ & $\begin{array}{l}\text { Post-test: } \\
\text { Reading } \\
\text { test 2 } \\
(2002 / 6)\end{array}$ & $\begin{array}{l}\text { Post-test: } \\
\text { Listening } \\
\text { test 3 } \\
(2002 / 6)\end{array}$ \\
\hline Mean & 79.91 & 94.35 & 77.39 & 91.89 & $93.25^{*}$ \\
$\mathrm{SD}$ & 19.11 & 10.37 & 17.89 & 11.51 & 16.49 \\
Passing N $(\%)$ & $17(50 \%)$ & $31(91.2 \%)$ & $17(47.2 \%)$ & $32(88.9 \%)$ & $29(80.6 \%)$ \\
$\mathrm{N}$ & 34 & 34 & 36 & 36 & 36 \\
\hline
\end{tabular}

Note: Listening test 1 and test 3 used the same test.

\section{Note}

* The research was funded by the National Science Council (NSC90-2411-H-002045). 


\section{References}

Belanoff, Patricia and Marcia Dickson (eds.) (1991). Portfolios: Process and Product. Portsmouth, NH: Boynton/Cook.

Brown, H. Douglas (2001). Teaching by Principles: An Interactive Approach to Language Pedagogy. 2nd edition. White Plains, NY: Addison Wesley Longman.

Brown, James Dean (ed.) (1998). New Ways in Classroom Assessment. Alexandra, VA: Teachers of English to Speakers of Other Languages.

Cohen, Andrew. D. (1998). Strategies in Learning and Using a Second Language. White Plains, NY: Addison Wesley Longman.

Farr, Roger and Bruce Tone (1994). Portfolio and Performance Assessment: Helping Students Evaluate Their Progress as Readers and Writers. Fort Worth, TX: Harcourt Brace College Publishers.

Fradd, Sandra and Sarah Hudelson (1995). Alternative assessment: A process that promotes collaboration and reflection. TESOL Journal 5 (1): 5.

Gottlieb, Margo (1995). Nuturing student learning through portfolios. TESOL Journal 5 (1): 1214.

Hewitt, Geof (1994). A Portfolio Primer: Teaching, Collecting, and Assessing Student Writing. Portsmouth, NH: Heinemann.

Horwitz, Elaine K. (1987). Surveying student beliefs about language learning. In Learner Strategies in Language Learning, Anita L. Wenden (ed.), 119-129. Englewood Cliffs, NJ: Prentice Hall.

McNamara, Martha J. and Debra Deane (1998). Self-assessment: Preparing an English portfolio. In New Ways in Classroom Assessment, James Dean Brown (ed.), 15-17. Alexandra, VA: Teachers of English to Speakers of Other Languages.

Mokhtari, Kouider, David Yellin, Kay Bull, and Diane Montgomery (1996). Portfolio assessment in teacher education: Impact on preservice teachers' knowledge and attitudes. Journal of Teacher Education 47 (4): 245-252.

Murphy, Sandra M. (1997). Who should taste the soup and when? Designing portfolio assessment programs to enhance learning. Clearing House 71 (2): 81-84.

Norris, J. M. (1996). Performance and Portfolio Assessment (1985-1995): An Extended Annotated Bibliography of Courses Useful for Language Teachers (Research Note). Honolulu: University of Hawaii, Second Language Teaching and Curriculum Center.

Nunan, David (1995). Likes and dislikes. Learning Matters: A Task-Based Course in Becoming a Better Learner (draft): 12. Hong Kong: The English Center, University of Hong Kong.

O'Malley, J. Michael and Anna U. Chamot (1990). Learning Strategies in Second Language Acquisition. New York: Cambridge University Press.

O'Malley, J. Michael and L. Valdez Pierce (1996). Authentic Assessment for English Language Learners: Practical Approaches for Teachers. Reading, MA: Addison-Wesley.

Oxford, Rebecca L. (1989). Strategy Inventory for Language Learning (SILL). Version 7.0 (EFL/ ESL). Alexandria, VA: Oxford Associates.

- (1990). Language Learning Strategies: What Every Teacher Should Know. Boston: Heinle and Heinle.

- (1993). Research on second language learning strategies. In Annual Review of Applied Linguistics 13, William Grabe (ed.), 175-187. Cambridge: Cambridge University Press.

Oxford, Rebecca L. and Betty L. Leaver (1996). A synthesis of strategy instruction for language learners. In Language Learning Strategies around the World: Crosscultural Perspectives, Rebecca L. Oxford (ed.), 227-246. Manoa: University of Hawaii Press.

Paulson, F. Leon and Peal R. Paulson (1991). Portfolios: Stories of knowing. Paper presented at the Annual Meeting of the Claremont Reading Conference. (ERIC Reproduction Service No. ED377209).

Paulson, F. Leon, Peal R. Paulson, and A. Meyer (1991). What makes a portfolio a portfolio? Educational Leadership 48 (5): 60-63. 
Reed, Candi Mascia (1997). Grammar and student portfolios: Self-evaluation and pride in learning. Perspectives in Education and Deafness 16 (2): 2-3.

Spence, Sarah L. and Billie Theriot (1999). Portfolios in progress: Reevaluating assessment. Research and Teaching in Developmental Education 15 (2): 27-34.

Terwilliger, James S. (1997). Portfolios and classroom assessment: Some claims and questions. (ERIC Reproduction Service No. ED419000).

Weinstein, Claire E. and Vicki L. Underwood (1985). Learning strategies: The how of learning. In Thinking and Research Skills: Relating Instruction to Research, Judith W. Segal, Susan F. Chipman, and Robert Glaser (eds.), 241-258. Hillsdale, NJ: Erlbaum.

Wenden, Anita (1991). Learner Strategies for Learner Autonomy: Planning and Implementing Learner Training for Language Learners. Hertfordshire, UK: Prentice Hall.

Williams, Marion and Robert L. Burden (1997). Psychology for Language Teachers: A Social Constructivist Approach. Cambridge: Cambridge University Press.

Yang, Nae-Dong (1992). Second language learners' beliefs about language learning and their use of learning strategies: A study of college students of English in Taiwan. Ph.D. diss., University of Texas.

- (1996). Effective awareness-raising in language learning strategy instruction. In Language Learning Strategies around the World: Crosscultural Perspectives, Rebecca L. Oxford (ed.), 205-210. Manoa: University of Hawaii Press.

- (1999). The relationship between EFL learners' beliefs and learning strategy use. System 27: $515-535$.

- (2002). Using portfolios as a learning tool. Paper presented at the 13th World Congress of the International Association of Applied Linguistics, Singapore.

Yueh, Hsiu-Ping (1999). Theory and practice of portfolios. In Handbook for Portfolio Workshop, 1-10. Taipei, Taiwan: National Taiwan University. 